Article

\title{
Human Resource Disclosures in Corporate Annual Reports of Insurance Companies: A Case of Developing Country
}

\author{
Fatma Bulut Sürdü ${ }^{1}$, Arzu Özsözgün Çalışkan ${ }^{2}$ a and Emel Esen ${ }^{2, *}$ (1) \\ 1 Social Sciences Institute, Y1ldız Technical University, Istanbul 34210, Turkey; fbbulut@gmail.com \\ 2 Business Administration Department, Faculty of Economics and Administrative Sciences, Yildiz Technical \\ University, Istanbul 34210, Turkey; ozsozgun@yildiz.edu.tr \\ * Correspondence: emeloz@yildiz.edu.tr
}

Received: 19 March 2020; Accepted: 21 April 2020; Published: 23 April 2020

check for updates

\begin{abstract}
Employees are key stakeholders for companies to maintain their sustainability. Obtaining and disclosing information related to employees can help companies to manage and evaluate the effectiveness of human resources. This paper investigates human resource disclosures in corporate annual reports of 54 insurance companies in Turkey and identifies the determinants of the disclosure for the period of 2007-2017. For this purpose, human resource disclosures with eight subdimensions as employee health and safety, employment of minorities or women, disabled employee, employee training, employee assistance and benefits, employee remuneration, employee profiles and employee morale were obtained from corporate annual reports by content analysis. The data were statistically tested with correlation analysis and a pooled OLS (Ordinary Least Squares) models to determine the effects of return on assets, return on equity, leverage, firm size, number of employees, age of firm, public listing status, foreign ownership, company type on these disclosures. The results indicate that number of employees, foreign ownership and company type have an effect on the extent of human resource disclosure. Employee training is the most disclosed item among human resource disclosures in corporate reports. It is suggested that companies should improve their reporting and disclosure practices related to human resource development.
\end{abstract}

Keywords: human resource disclosures; insurance sector; corporate reports; developing country

\section{Introduction}

In this paper, the research question is formulated as "what are the extent of human resource disclosure in corporate annual reports?" and "which determinants are related with the human resource disclosures in corporate annual reports of insurance companies?"

Human resources are the most vital assets of the companies to maintain their sustainability since they are source of the knowledge, skills, and competence. Sustainability has three aspects-economic, social, and environmental-and a sustainable company not only survive itself but only contribute to the sustainable development by producing value for economy, society and environment. In line with being a sustainable company, the company needs to respond promptly to their stakeholders' demand. For that reason, human resource disclosure is valuable for organizations to provide information about efficiency and effectiveness of their human resource practices to management and society [1]. It creates benefit not only for employees but also has a good influence on corporate reputation [2]. Stakeholders demand to be informed about the effect of human resources on company's value and concern the effect of organizations on employees' wellbeing [3]. Therefore, there is a need to understand how human resources information are voluntarily reported in corporate reports [4]. Human resource disclosing 
tries to report the financial consequences of factors possessed by employees and entire workforce of an organization [5].

The main aim of this study is to assess the extent of human resource disclosures and the determinants of the human disclosures in corporate annual reports of insurance companies. This study is valuable to understand the human resources disclosures in corporate reports of insurance companies. Insurance sector is an important sector for our country's economy and sustainable development. Therefore, examining human resources disclosing patterns as employee health and safety, employment of minorities or women, disabled employees, employee training, employee assistance/benefits, employee remuneration, employee profiles and employee morale in this sector will create value for society and all stakeholder groups.

For this purpose, 54 companies' corporate annual reports covering the 11-year period between 2007-2017 in insurance sector were analyzed. Annual reports were obtained from their corporate web sites for potential total of 594 firm year observations. In these reports, human resource disclosures were gathered manually and the factors as return on assets (ROA), return on equity (ROE), leverage, firm size, number of employees, age of firm, public listing status (BIST), foreign ownership, company type that influence human resource disclosures were analyzed statistically.

The contribution of the paper to literature is as follows. First, limited empirical studies investigated the human disclosures and determine which factors were associated with the extent of human resource disclosures in corporate annual reports. Although, in previous studies, various characteristics influence the extent and theme of disclosure in annual reports and in various developed countries [5-9], there is lack of studies that investigate companies in developing countries such as Turkey. Specifically, corporate social responsibility (CSR) disclosure (i.e., human resource, products and consumers and community involvement disclosure) was paid more attention in developed countries than developing countries [10]. Therefore, this study contributes the literature by conducting developing country study in human resource disclosure. In addition, this paper takes into account the insurance sector that have an important role in economic system and sustainable development. A full-grown insurance sector is an important part of financial sector and it is necessary for the sustainable development of emerging countries, like Turkey. Since the companies generally invest in corporate debt, they play an essential role in allocating capital and funds to productive investment projects [11]. Insurance companies also support the processes of sustainable development and efficiency of other sectors by enabling companies and people to transfer of risk they face as well as by helping to channel savings into investment [12]. In the last decades, insurance companies have become an indispensable actor on financial markets and sustainable development. Because they are the largest institutional investors, manage billions of dollars and own one-third of global assets [13]. As of 31 December 2017, a total of 62 active insurance, pension and reinsurance companies operated in Turkey. Thirty-eight of these are non-life insurance, four companies are life insurance, eighteen companies are pension and two companies are reinsurance companies. According to Pension Monitoring Center in Turkey, there are 15,782 licensed and registered insurance agencies. In addition, there are also 48,039 authorized pension agents. By the end of the 2018 , insurance sector in Turkey directly employs more than 200,000 people [14].

This paper comprises of the following main sections. The first section presents an understanding of human resource disclosures and the importance of these disclosures in corporate annual reports. Second section explains research methodology and the next section presents the results of the study. In conclusion part, research findings are discussed, limitations and recommendations for further studies are given. 


\section{Theoretical Framework}

\section{Human Resource Disclosures}

Business practitioners, organizational theorists and researchers are interested in human resource and human capital disclosures since last 1980s [15]. For intangible assets-based companies, intellectual capital became a popular term during the 1990s. Intellectual capital is considered as the positive difference between the market value and the book value of a company [16]. Several studies investigated the human capital disclosures, more generally intellectual capital composed of human capital, structural capital and relational capital [17]. Human capital includes know-how, education, employees, work related knowledge and work-related competence in intellectual framework of Bozzolan et al.'s [18] study. Pisano et al. [17] identified human capital disclosure items in their study. The items were grouped into two items: Stock of knowledge and capabilities and human resource management practices. Human resource management practices were categorized as recruitment, training, career development, welfare and motivation, health and safety, union activity. On the other hand, Dhaliwal et al. [19] examined a broader concept of corporate social responsibility actives with many dimensions, one group of dimensions represented human resources (HR) activities as employee relations, diversity practices and human rights. Chan et al. [20] used human resources items in content analysis to measure disclosed information. Employee wellbeing, health and safety, physical working conditions, intangible working conditions (recognition, work-life balance, decision making, satisfaction), training and development, equity and diversity are used measurement items. Consequently, both intellectual capital disclosures and corporate social responsibility disclosures in previous studies formed the human resource disclosures items in this study.

Voluntary disclosure is a tool that based on managerial motivator to meet business targets and be aware of the changes in the environment [21]. It refers to the level of the information that are not obliged to disclose by regulations [22]. The voluntary disclosure of human resources information increase users' understanding and perceptions about the organization's performance and sustainability. Human resource disclosures allow organizations to communicate with their employees and reach them about crucial information, reduce rumors and misunderstanding among employees [1]. Disclosing human resources information in corporate annual reports satisfied companies and report users' needs and expectations about the importance of human resources that contributes to sustainability. Certainly, due to social, cultural, and environmental factors in different nations, the frequency and amount of disclosed information would be different [23]. Arvidsson [24] categorized the nonfinancial information in corporate annual reports. The most focused non-financial information is organizational information which is related to organizational processes organizational performance, product quality and corporate culture. The second category is human related information as managerial board, managers, employees, team, competence development program and incentive programs. In human category, nonfinancial key performance indicators (KPIs) are human capital index, human related criterion, employer attractiveness, employee satisfaction, employee turnover, annual wages and sick days. Stone [25] defined human resources as the "productive use of people in achieving the organization's strategic business objectives and the satisfaction of individual employee needs" [26]. Companies are increasingly relied on from tangible assets to intangible assets in innovation, knowledge driven world [24]. Bukh [27] made an analysis of annual reports about human resources information and stated that information should be disclosed as an integral part of the value creation for sustainable organizations. 
Table 1 represents the recent studies about human resource disclosures in corporate reports. Kaur [28] analyzed the extent of HR disclosures of CNX (Indian Stock Exchange Index) 200 firms listed on National Stock Exchange in India. He used HR disclosure item as employee strength, attrition/turnover rate, training and development, staff distribution, employee experience, employee age and employee education, employee performance indicators, employee participation, presence of HR department, human resources awards, employee satisfaction survey, retirement, whistleblowing policy, EVA (economic value added) disclosure, health, safety and welfare of employees and labor relations. Vuontisjarvi [29] researched the human resources practices in annual reports. Themes were used in content analysis: training and staff development, pays and benefits, participation and staff involvement, values and principles, employee health and wellbeing, employment policies, security, equal opportunities, work-life balance. Dominquez [30] investigated the determinants of corporate disclosure on human resources and used information categories about human resources. These are information on human capital, social information and ethical information. Brown et al. [1] examined human resource development issues in the annual reports. Eight categories of human resources disclosures (HRD) as health and safety, employment minorities or women, employee assistance/benefits, employee profiles, employee morale and relations, industrial relations, training initiatives and other factors. Petera and Wagner [3] investigated HR disclosure as a specific area of corporate responsibility reporting in the annual reports. Abeysekara and Guthrie [5] examined the disclosure patterns of human capital reporting in the sample. Human capital attributes are used to measure human capital. These attributes are know-how, education, vocational qualifications, employee involvement, career development, entrepreneurial spirit, innovativeness, abilities, training programs, equity issues, employment safety, employee growth, efficiency, and stability ratios. 
Table 1. Recent studies about human resources disclosures in reports.

\begin{tabular}{|c|c|c|c|c|c|c|}
\hline Authors & Kaur et al. 2015 & Vuontisjarvi 2006 & Dominguez 2012 & Brown et al. 2005 & Petera and Wagner 2017 & $\begin{array}{l}\text { Abeysekara and } \\
\text { Guthrie } 2004\end{array}$ \\
\hline Country & India & Finland & Spain & Pacific Island Countries & Czechia & Sri Lanka \\
\hline Sample & $\begin{array}{l}\text { CNX } 200 \text { companies listed on National } \\
\text { Stock Exchange }\end{array}$ & $\begin{array}{l}205 \text { biggest Finnish } \\
\text { companies }\end{array}$ & $\begin{array}{l}105 \text { Spanish Listed } \\
\text { Companies }\end{array}$ & $\begin{array}{c}9 \text { developing } \\
\text { countries-number of } \\
\text { companies are not available }\end{array}$ & 50 largest companies & $\begin{array}{l}\text { Companies in Sri } \\
\text { Lanka }\end{array}$ \\
\hline $\begin{array}{l}\text { Independent } \\
\text { variables }\end{array}$ & $\begin{array}{l}\text { Structural, Performance, Market, } \\
\text { Internal management structure }\end{array}$ & - & $\begin{array}{l}\text { Size, leverage level, } \\
\text { degree of ownership } \\
\text { concentration, type of } \\
\text { industry, profitability }\end{array}$ & $\begin{array}{l}\text { Societal factors, business } \\
\text { environment, } \\
\text { organizational attributes, } \\
\text { size }\end{array}$ & $\begin{array}{l}\text { Company size, listing } \\
\text { status of the company, } \\
\text { governmental influence, } \\
\text { leverage, employee } \\
\text { expenses, issuing a } \\
\text { standalone sustainability } \\
\text { report, belonging a new } \\
\text { economy }\end{array}$ & - \\
\hline Report type & Annual report & Annual report & Annual reports & Annual reports & Annual reports & Annual reports \\
\hline Dependent variables & $\begin{array}{l}\text { HRDI (Human Resource Disclosure } \\
\text { Index) }\end{array}$ & $\begin{array}{l}\text { Human resource } \\
\text { disclosures }\end{array}$ & $\begin{array}{l}\text { Human resource } \\
\text { disclosure }\end{array}$ & HRD Index & $\begin{array}{l}\text { Human resources } \\
\text { disclosure }\end{array}$ & $\begin{array}{l}\text { Human capital } \\
\text { reporting }\end{array}$ \\
\hline Findings & $\begin{array}{l}\text { The study showed high correlation } \\
\text { between HRDI and market } \\
\text { capitalization, governmental ownership, } \\
\text { human resources committee, firm age } \\
\text { and profitability employee expense ratio } \\
\text { and foreign investment. }\end{array}$ & $\begin{array}{l}\text { The most used HRD } \\
\text { theme was found as } \\
\text { training and staff } \\
\text { development. }\end{array}$ & $\begin{array}{l}\text { Company size, } \\
\text { industry type, } \\
\text { property have impact } \\
\text { on the disclosure. }\end{array}$ & $\begin{array}{l}\text { Human resource disclosure } \\
\text { and ethnic background, } \\
\text { industry, entity, and size } \\
\text { attributes are not significant } \\
\text { in research model. }\end{array}$ & $\begin{array}{l}\text { Company size and } \\
\text { presence of securities were } \\
\text { associated with HR } \\
\text { disclosure }\end{array}$ & $\begin{array}{l}\text { Employee } \\
\text { contribution was the } \\
\text { most notable human } \\
\text { capital attribute. }\end{array}$ \\
\hline
\end{tabular}




\section{Methodology}

\subsection{Sample and Data Collection}

The sample comprises 501 firm-year observations for human resources disclosures from the corporate annual reports of insurance companies in Turkey between 2007-2017, which are selected in the following manner. First, all insurance companies in Turkey were identified. There are 62 insurance companies in Turkey for the year 2017. Second, annual reports are downloaded for 54 of these firms were available from their corporate web sites for potential total of 594 firm year observations (11 years, 2007-2017). Our data set covers insurance firms that were actively operating for the 11 years from 2007 to 2017. Since some of the companies do not have active corporate Internet web pages in the period, there were missing reports and the final sample includes 54 firms and from their receivable reports, 501 firm-year observations. Table 2 presents the sample selection procedure.

Table 2. Sample description.

\begin{tabular}{cc}
\hline Sample & Number \\
\hline Number of expected observations & 594 \\
\hline Company-years without necessary information & 93 \\
\hline Number of final observations & 501 \\
\hline
\end{tabular}

The data were provided manually from corporate annual reports of Turkish insurance companies during the time period from 2007 to 2017. The standard contents of Turkish insurance companies' annual reports have three main parts. These are the general information about the companies, the information regarding the management and corporate management practices and detailed financial information and assessments regarding risk management. All the financial statements in the annual reports are in line with the Turkish Financial Reporting Standards (TFRS) [31]. TFRSs are in full compliance with the International Financial Reporting Standards (IFRS) [32]. All financial variables are collected from annual reports that involve audited financial statements. Insurance firms in our sample constitutes roughly $87 \%$ of insurance companies actively operating in Turkey over our period of analysis and comprises a mix of companies of varying size, ownership type and number of employees. Having a sample that reflects the structure of the sector assists to increase the strength of the test conducted and thereby supports the reliability of the results.

\subsection{Measurement Instruments}

Content analysis method was used in the study consistent with other similar studies [28,33-35]. The method enables to classify the information disclosed into several categories of items which involve the aspects of human resources disclosure [34] and helps researcher to test theoretical issues to improve understanding of the data [36].

Table 3 presents the eight disclosures items related to human resources that used content analysis. The items were adopted from prior studies in the accounting literature for sample companies [34,37-43]. First, based on literature review, human resources related disclosure items were identified. In case of insurance companies, human resources related disclosure comprises employee health and safety, employment of minorities or women, disabled employee, employee training, employee assistance/benefits, employee remuneration, employee profiles and employee morale as shown in Table 3. Thereafter, in order to ensure consistency and to test the reliability and validity of the items, using a structural coding format, a pilot study conducted on five insurance companies' corporate annual reports. To eliminate inter-coder reliability problems, all data were collected by only one researcher [33]. The data related to human resources disclosure based on information provided in corporate annual reports. In order to provide an extended longitudinal content analysis, corporate annual reports were collected from 2007 until 2017. 
Table 3. Items of disclosures.

\begin{tabular}{|c|c|}
\hline Human Resource Disclosures & References \\
\hline Employee health and safety & $\begin{array}{c}\text { Branco and Rodrigues [34], Bayoud et al. [37], Das [38], Gamerschlag et al. [39], } \\
\text { Ismail and Ibrahim [40], Menassa [41], Suher [42], Tagesson et al. [43] }\end{array}$ \\
\hline Employment of minorities or women & $\begin{array}{c}\text { Branco and Rodrigues [34], Bayoud et al. [37], Gamerschlag et al. [39], Menassa [41], } \\
\text { Tagesson et al. [43] }\end{array}$ \\
\hline Disabled employee & Bayoud et al. [37], Ismail and Ibrahim [40] \\
\hline Employee training & $\begin{array}{l}\text { Branco and Rodrigues [34], } \\
\text { Das [38], Gamerschlag et al. [39], Ismail and Ibrahim [40], Menassa [41], Suher [42], } \\
\text { Tagesson et al. [43] }\end{array}$ \\
\hline Employee assistance/benefits & Branco and Rodrigues [34], Das [38], Menassa [41] \\
\hline Employee remuneration & Branco and Rodrigues [34], Menassa [41] \\
\hline Employee profiles & $\begin{array}{c}\text { Branco and Rodrigues [34], Bayoud et al. [37], Ismail and Ibrahim [40], Menassa [41], } \\
\text { Tagesson et al. [43] }\end{array}$ \\
\hline Employee morale & Branco and Rodrigues [34], Menassa [41], Suher [42] \\
\hline
\end{tabular}

\subsection{Research Model and Variables}

Table 4 represents the dependent variable and independent variables of research model. We use following models to test the hypotheses of this study. The model used for the regressions analysis is expressed in the general form as given in Equations (1) and (2).

$$
\text { HRDS }=\mathrm{f}(\text { ROA, ROE, LEV, SIZE, NEP, AGE, BIST, FOREIGN, TYPE) }
$$

$$
\begin{gathered}
\text { HRDS }_{\text {it }}=\alpha_{0}+\beta_{1} \text { ROA }_{i t}+\beta_{2} \text { ROE }_{i t}+\beta_{3} \text { LEV }_{i t}+\beta_{4} \text { SIZE }_{t}+\beta_{5} \mathrm{NEP}_{i t}+\beta_{6} \mathrm{AGE}_{i t}+\beta_{7} \text { BIST }_{i t}+ \\
\beta_{8} \text { FOREIGN }_{i t}+\beta_{9} \text { TYPE }_{i t}+\beta_{10} \text { YEAR DUMMY }_{\varepsilon i}
\end{gathered}
$$

where HRDS $_{\text {it }}$ : the human resource disclosures of company i between 2007-2017 (the natural logarithm of total sentence number linked to the employee issues in the company's annual report), $\alpha_{0}=$ intercept, ROA: Return on assets of firm $\mathrm{i}_{\mathrm{i}}$ ROE: Return on equity of firm $\mathrm{i}_{\mathrm{i}}$ LEV: Leverage of firm $\mathrm{i}_{\mathrm{i}}$, SIZE: Size of firm ${ }_{i}$, NEP: Number of employees of firm ${ }_{i}$, AGE: Age of firm ${ }_{i}$, BIST: Public listing status of firm,

\begin{tabular}{|c|c|}
\hline \multicolumn{2}{|r|}{ Variables } \\
\hline \multicolumn{2}{|r|}{ Dependent Variable } \\
\hline HRDS & $\begin{array}{c}\text { Human Resources Disclosure Score-measured as natural logarithm of human } \\
\text { resource disclosure }\end{array}$ \\
\hline \multicolumn{2}{|r|}{ Independent Variables } \\
\hline ROA & Return on assets-net income to total assets \\
\hline ROE & Return on equity-net income to total equity \\
\hline LEV & Leverage-total liabilities to total assets \\
\hline SIZE & Firm size-natural logarithm of total assets \\
\hline NEP & Number of Employees \\
\hline AGE & Firm age- - The number of years since the firm's inception \\
\hline BIST & $\begin{array}{l}\text { The existence of securities on the Borsa Istanbul (BIST-1 if the insurance company } \\
\text { listed on BIST, } 0 \text { - otherwise) }\end{array}$ \\
\hline FOREIGN & Foreign ownership -1 if the insurance company has foreign ownership, 0 - otherwise \\
\hline TYPE & Type of company-1 if the insurance company is life insurance, $0-$ otherwise \\
\hline
\end{tabular}
FOREIGN: Foreign ownership of firm ${ }_{i}$, TYPE: Type of firm ${ }_{i}, \varepsilon i$ : random error term.

Table 4. Variable definitions.

\subsubsection{Dependent Variable}

Human resources disclosure in corporate annual reports was collected manually via content analysis. Eight categories were pre-defined to assess objectively human resources related information based on a review of accounting literatures [34,37-43]. Disclosure related to employee health and safety, employment of minorities or women, disabled employee, employee training, employee 
assistance/benefits, employee remuneration, employee profiles and employee morale are defined as human related disclosures [34,37-43]. The data related to human resources disclosure based on information provided in annual reports. In order to provide an extended longitudinal content analysis, annual reports were collected from 2007 until 2017.

In literature, number of words are also used to measure companies' disclosure, but these are controversial measure because the measures can be affected by print sizes, column sizes and page sizes and these items could be different from one annual report to another. In addition, using the number of words to measure human disclosure amount would not be appropriate since it could not reveal embedded meaning of context [44]. In order to deal with the drawbacks, the measure of human resources disclosure and content category is number of sentences [45], since it is more reliable than any other unit of analysis [44] and in line with the aim of the study and literature sentiment analysis is not taken into account [45].

Insurance companies' annual reports were used to collect human information about the companies' human resources disclosure, because annual reports are mandatory and important traditional sources of corporate information and communication medium for companies [46-48]. By means of annual reports, companies could disclose financial and various non-financial, voluntary issues and could create an image in the minds of its stakeholders about how corporate life is in their company and present snapshot' of the mindset of corporate management [47]. Table 3 depicts the eight disclosures items related to human resources that used content analysis of annual reports.

\subsubsection{Independent Variables}

As stated previously, the aim of this study is to investigate the human resources disclosure practice' of insurance companies by Turkish companies and to analyze the potential relationship between a number of insurance companies' characteristics-in particular, return on assets (ROA), return on equity (ROE), leverage (LEV), size (SIZE), number of employees (NEP), firm age (AGE), public listing status (BIST), foreign ownership (FOREGING) and type of firm (TYPE) — and the extent of human resources disclosure. In line with this aim, several hypotheses are examined:

\subsubsection{Return on Assets (ROA)}

According to the previous studies, the relationship between companies' return on assets (ROA) and disclosure level was considerably examined. However, there is no consensus on the results [43,49-51]. One side supports the idea that the more profitable companies disclose the more information voluntarily [52-55]. The other side support the idea that there is no connection between companies' profitability and voluntarily disclosure level $[49,56,57]$. Although the results are controversial, companies with high return on assets could have more extent human resources disclosure level. Supporting argument for this stance is based on the idea that having good financial performance are in better to allocate more resources to bear the cost of identifying, collecting and reporting for the information needed for human resources disclosure [58,59]. Furthermore, according to human resources literature, better human resources management also create positive effect on the companies' financial performance by reducing cost, enhancing human resources productivity and creating a competitive advantage $[33,60]$. In addition, that the management of companies with a great economic performance disclose more detailed information to sustain its own position and compensation and show a greater willingness to disclosure $[28,43]$. For that reason, we proposed our hypothesis as:

Hypothesis 1 (H1). The extend of human resources disclosure is positively associated with return on assets.

\subsubsection{Return on Equity (ROE)}

In the literature, return on equity is seen as the measurement of financial performance [59]. And, human resources are an intangible asset and is the most vital factor for creating value and for 
achieving sustainable financial performance. According to literature, more profitable firm disclose more voluntarily information. Because they are generally under intense scrutiny by public and by disclosing voluntarily non-mandatory information, they create a self-regulation mechanism to avoid public examine $[50,58]$. In addition, that companies with high return on equity is more willing to disclose more information in its annual report in order to highlight its superior performance [51]. Thus, our second hypothesis is proposed as:

Hypothesis 2 (H2). The extend of human resources disclosure is positively associated with return on equity.

\subsubsection{Leverage}

Leverage (LEV) presents the structure of financing the company measured by total debt to total assets. According to agency theory, companies have to aware and response the needs of fund providers and by disclosing more comprehensive information both about financial and non-financial elements of their value creation. By this way companies could avoid informative asymmetries and reduce agency cost [61-63]. Companies with high leverage need to have to disclose more and detailed information in their annual reports than those who have less leverage to attract outside financing [60]. The relationship between leverage and firm disclosure level are subjected to empirical researches. However, the results are dubious [51], some of the studies propound significant relationship [63-65], while others suggest insignificant relationship $[28,66,67]$. Hence, the third hypothesis is proposed as:

Hypothesis 3 (H3). The extend of human resources disclosure is positively associated with leverage of firm.

\subsubsection{Size}

The size of a company is an important constituent of human resources disclosure. It affects the ability of firm to disseminate human resources related information to stakeholders. The more disclosed information about the elements of companies' value creation the more investment tends to firms. And so, the companies are able to receive lower-priced funds $[30,61,68]$ and trustworthy disclosure enhance value since it supports investor decision making [69]. In addition, that the larger companies are in the spotlight of the government agencies and society. For that reason, better disclosure practices could be a way for companies to diminish the pressure [28]. There are number of empirical researches that examine the effect of size on human resources disclosure $[3,28,30,63,65,68]$. Hence the fourth hypothesis is proposed as:

Hypothesis $4 \mathbf{( H 4 ) .}$. The extend of human resources disclosure is positively associated with size of firm.

\subsubsection{Number of Employees}

Number of employees (NEP) is accepted as the proxy for public visibility and a measure of size $[28,49,50]$. Companies with a greater number of employees may be interested particularly by unions, general public, and members of government [34,70]. For that reason, the companies may disclose more information about their employees to avoid the scrutiny. Several empirical studies have found significant relationship between number of employees and the extend of human resources disclosure $[3,28,39,41,43]$. Hence, based on the literature the fifth hypothesis is proposed as:

Hypothesis $\mathbf{5}$ (H5). The extend of human resources disclosure is positively associated with number of employees of firm. 


\subsubsection{Firm Age}

The firm age could influence its practices since it is seen as a sign of development and growth stage [28]. Junior companies could have disadvantage of dissemination of information such as research expenditure, capital expenditure and product development. Because this information could be used by their competitors and result in competitive disadvantages. Conversely, mature companies more experienced about their competitive position and their competitors, thus the dissemination risks could be assessed from different perspectives. The other disadvantage for junior companies is due the cost and the ease of gathering, processing, and disseminating the required information. These costs could be more severe for junior companies than for their mature counterparts. Lastly, junior companies may lack of performance history that help them to obtain the support of public confidence [71].

For that reason, mature firms disclose more human resources related information [72-74]. According to legitimacy theory, the age of firm has effect on its company reputation in the community and to be engaged historically in non-financial disclosure [41,73]. In the literature, the empirical results of the relationship between firm age and disclosure practices are varied. While some of the studies found significant relationship [21,71,73], others suggest insignificant relationship [75,76]. Hence, based on the literature the sixth hypothesis is proposed as:

Hypothesis 6 (H6). The extend of human resources disclosure is positively associated with firm age.

\subsubsection{Public Listing Status}

Listed companies regularly disclose information to the stakeholders. The information that companies disclose is helpful to communicate its investors and creditors and to meet their fund demand [41]. In order to provide fund investors, require the complete detail of future earnings and value creation and human resources disclosure is an important element to understand value creation abilities of insurance companies.

In addition, that it is widely accepted that being publicly listed increases the number of stakeholders and these stakeholders required to be informed. For that reason, listed companies disclose more information than determined by regulation and non-listed companies to overcome the pressure and to become more visible and accountable [77]. In the literature, there are some studies that report significant relations between public listing status and corporate disclosure $[50,66,73,78]$, while others suggest insignificant relationship [41,79]. Thus, the following hypothesis was developed:

Hypothesis 7 (H7). The extend of human resources disclosure is positively associated with the existence of securities on the Borsa Istanbul (BIST).

\subsubsection{Foreign Ownership}

Foreign ownership is one of the most used variables to explain companies non-financial, voluntary disclosure [77]. The larger portion of foreign ownership would affect the disclosure policy of the company since the owner demand more human resources related information $[28,80,81]$. In addition, that the firms' more extensive disclosure may enable to reduce investor uncertainty and the firms' cost of capital [81]. Thus, it is proposed that the portion of foreign ownership create positive effect on human resources disclosure. For that reason, the following eighth hypothesis was developed:

Hypothesis 8 (H8). The extend of human resources disclosure is positively associated with foreign ownership of firm. 


\subsubsection{Type}

Insurance companies as a manager of risk has an important influence on social and economic development of every sector and society. Specifically, life insurer companies, contribute sustainable development. Due to active position in the society, these companies promote peer companies to employ better governance and citizenship [74]. Type of insurance companies, life insurers or non-life insurers, may create effect on insurance companies' disclosure policy. For example, life insurance companies disclose more corporate social responsibility information than non-life insurance companies do [38]. On the other hand, Ullah et al. [74] observe that life insurance companies disclose more corporate social responsibility disclosure. For that reason, we would like to suggest following hypothesis:

Hypothesis 9 (H9). The extend of human resources disclosure is positively associated with type of firm.

\subsection{Data Analysis}

\subsubsection{Descriptive Statistics}

Table 5 shows the descriptive statistics for the dependent and independent variables used in this study. The human resources disclosures scores range from 0 to 4.44 with a mean of 2.299. Return on assets ranging from -1.174 to 0.706 with a mean of -0.011 and its standard deviation is 0.126 . Not only ROA but also return on equity ranging from -217.58 to with 5.933 with a mean of -0.615 and its standard deviation is 9.948. It is revealed that the companies in the sample have negative ROE since the most of them have net loss. As a robustness test, all firm/year observations with negative ROE excluded from the sample and very similar results are found [82]. Leverage ranging from -3.900 to 1.701 with a mean of 0.742 and size of insurance companies ranging from 11.627 to 23.606 with a mean of 1.731. Number of employees ranging from 2 to 2260 with a mean of 334.163 and its standard deviation is 336.711. Firm ages ranging from 1 to 100 with a mean of 28.510 .

Table 5. Descriptive statistics.

\begin{tabular}{cccccc}
\hline Variables & $\mathbf{N}$ & Mean & SD & Min & Max \\
\hline HRDS & 501 & 2.299 & 0.991 & 0 & 4.44 \\
ROA & 501 & -0.011 & 0.126 & -1.174 & 0.706 \\
ROE & 501 & -0.615 & 9.948 & -217.58 & 5.933 \\
LEV & 501 & 0.742 & 0.275 & -3.900 & 1.701 \\
SIZE & 501 & 19.839 & 1.731 & 11.627 & 23.606 \\
NEP & 501 & 334.163 & 336.711 & 2 & 2260 \\
AGE & 501 & 28.510 & 25.6198 & 1 & 100 \\
BIST & 501 & 0.147 & 0.355 & 0 & 1 \\
FOREIGN & 501 & 0.522 & 0.499 & 0 & 1 \\
TYPE & 501 & 0.395 & 0.489 & 0 & 1 \\
\hline
\end{tabular}

Table 6 presents a detailed data and summary information regarding the distribution of human resources disclosures based on subject in annual reports of Turkish insurance companies. Subject of human resources disclosure in annual reports between 2007-2017 are presented in detail. This analysis implies that insurance companies in the sample, mainly disclose information about employee training. The second most disclosed information employee morale. And the third highest disclosed item is employee profiles. The result indicate that the least disclosure is disabled employee. Employment of minorities or women is the second least disclosed item in the sample. 
Table 6. Number of human resource disclosures.

\begin{tabular}{|c|c|c|c|c|c|c|c|c|c|c|c|c|c|c|c|c|c|c|c|c|c|c|c|c|}
\hline \multirow[t]{2}{*}{ Human Resource Disclosure } & \multicolumn{2}{|c|}{2007} & \multicolumn{2}{|c|}{2008} & \multicolumn{2}{|c|}{2009} & \multicolumn{2}{|c|}{2010} & \multicolumn{2}{|c|}{2011} & \multicolumn{2}{|c|}{2012} & \multicolumn{2}{|c|}{2013} & \multicolumn{2}{|c|}{2014} & \multicolumn{2}{|c|}{2015} & \multicolumn{2}{|c|}{2016} & \multicolumn{2}{|c|}{2017} & \multicolumn{2}{|c|}{ Total } \\
\hline & No & $\%$ & No & $\%$ & No & $\%$ & No & $\%$ & No & $\%$ & No & $\%$ & No & $\%$ & No & $\%$ & No & $\%$ & No & $\%$ & No & $\%$ & No & $\%$ \\
\hline Employee health and safety & 13 & 3.78 & 19 & 3.54 & 20 & 3.55 & 24 & 3.61 & 25 & 3.37 & 30 & 3.94 & 100 & 9.89 & 105 & 11.58 & 128 & 11.64 & 60 & 8.21 & 43 & 6.37 & 567 & 7.06 \\
\hline $\begin{array}{l}\text { Employment of minorities or } \\
\text { women }\end{array}$ & 1 & 0.29 & 1 & 0.19 & 6 & 1.06 & 2 & 0.30 & 2 & 0.27 & 3 & 0.39 & 15 & 1.48 & 5 & 0,55 & 7 & 0.64 & 0 & 0.00 & 3 & 0.44 & 45 & 0.56 \\
\hline Disabled employee & 0 & 0.00 & 0 & 0.00 & 4 & 0.71 & 7 & 1.05 & 3 & 0.40 & 5 & 0.66 & 3 & 0.30 & 0 & 0.00 & 0 & 0.00 & 3 & 0.41 & 0 & 0.00 & 25 & 0.31 \\
\hline Employee training & 151 & 43.90 & 232 & 43.28 & 245 & 43.44 & 303 & 45.56 & 326 & 43.99 & 355 & 46.59 & 458 & 45.30 & 407 & 44.87 & 454 & 41.27 & 278 & 38.03 & 202 & 29.93 & 3411 & 42.45 \\
\hline Employee assistance/benefits & 26 & 7.56 & 53 & 9.89 & 64 & 11.35 & 59 & 8.87 & 70 & 9.45 & 66 & 8.66 & 65 & 6.43 & 53 & 5.84 & 92 & 8.36 & 85 & 11.63 & 84 & 12.44 & 717 & 8.92 \\
\hline Employee remuneration & 31 & 9.01 & 47 & 8.77 & 52 & 9.22 & 71 & 10.68 & 71 & 9.58 & 67 & 8.79 & 81 & 8.01 & 63 & 6.95 & 111 & 10.09 & 51 & 6.98 & 44 & 6.52 & 689 & 8.57 \\
\hline Employee profiles & 76 & 22.09 & 105 & 19.59 & 81 & 14.36 & 101 & 15.19 & 108 & 14.57 & 105 & 13.78 & 95 & 9.40 & 102 & 11.25 & 93 & 8.45 & 78 & 10.67 & 60 & 8.89 & 1004 & 12.49 \\
\hline Employee morale & 46 & 13.37 & 79 & 14.74 & 92 & 16.31 & 98 & 14.74 & 136 & 18.35 & 131 & 17.19 & 194 & 19.19 & 172 & 18.96 & 215 & 19.55 & 176 & 24.08 & 239 & 35.41 & 1578 & 19.64 \\
\hline Total & 344 & & 536 & & 564 & & 665 & & 741 & & 762 & & 1011 & & 907 & & 1100 & & 731 & & 675 & & 8036 & \\
\hline
\end{tabular}


There is an increasing human resource disclosure trend in the period 2007-2013 and the year 2015 is the year with the highest human resource disclosure. During the financial crises in 2008-2009, the level of employment in the Turkish insurance sector decreased. And, then the employment in insurance sector gradually recovered following the contraction processes in 2008-2009. In line with the progress in employment level, human resource disclosures also were increasing. While there is a decreasing trend in the employment level in the sector, the companies start to disclose more information related to human disclosure. It would be interpreted that the companies may prefer to disclose more human resources related information to offset the decrease in the employment level. Not only macroeconomic conditions but also the financial conditions in the sector, technological developments, mergers and changing consumer behavior have effect on the employment structure of the sector and human resources disclosure [83]. As it seen from Table 6, thus, after the year 2015, the companies have started to disclose fewer human resources information in the sector and the increase trend in human resources disclosure, reverse results between 2016-2017. When it is analyzed, it is seen that there is a decreasing human resources disclosure trends in employee health and safety and employee training, employee renumeration related information. The reason of the disclose less information about the issue would be related to financial conditions in the sector, because, especially employee training and renumeration are the issues related with financial implications. The companies would choose to make less investment in these years to compensate the reduction in financial conditions of the sector in these years [83]. Thus, the firms have less information to disclose.

\subsubsection{Correlation Analysis}

Table 7 provides correlation matrix for the variables in the research. Human resource disclosures are positively and significantly correlated to ROA, LEV, SIZE, respectively with a correlation coefficient of $0.125,0.079,0.408$. This results in with our expectations and indicates that profitable firms, leveraged firms and larger firms are more likely disclose their human resources related information. Besides that, the correlation between HRDS and NEP, AGE, BIST, FOREIGN and TYPE is positive and statistically significant, with a correlation coefficient of $0.431,0.267,0.161$ and 0.214 , respectively. On the other hand, ROE is not statistically correlated to HRDS, contrary to our expectations. Finally, the highest correlation can be found between AGE and NEP $(0.716 ; p<0.001)$ and low correlation coefficient among all independent variables shows that multicollinearity problem is not presented in our analysis.

Table 7. Correlation matrix.

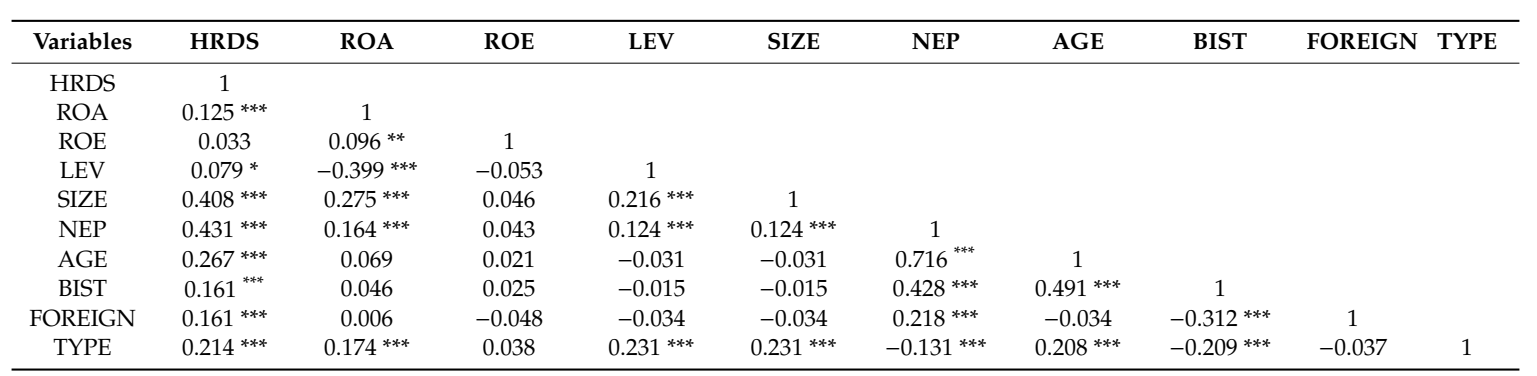

${ }^{*}{ }^{* *}$ and ${ }^{* * *}$ represents significance levels at $p<0.1 ; p<0.05$ and $p<0.01$, respectively. Please find the definitions of variables in Table 2.

\subsubsection{Regression Analysis}

Regression analysis a statistical technique which is used identifying the variables and also the technique is useful to determine the suitable regression strategy for citation data [84]. For regression count, some models can be used in previous research studies were suggested [85-87]. A pooled OLS model was employed in our analysis with the year dummy included in the model. The Cook-Weisberg and White test statistics are used in order to test homoskedasticity. The test results present the sign of heteroskedasticity [88-90]. To deal with heteroskedasticity, a robust-cluster estimator of the standard errors is used. The robust-cluster variance estimator is a variant of the Huber-White robust estimator. 
Using the estimator moderate the assumption of independence of errors in the regression. Repeated observations may cause correlated error terms and increase t-statistics without using this correction and it is expectable in a pooled time-series approach. Therefore, the robust-standard errors are unaffected by the presence of unmeasured firm-specific factors causing correlation among errors of observations for the same firms or for that matter any other form of within-unit error correlation. Consequently, the robust-cluster estimator produces correct standard errors even when the observations are correlated within clusters [90,91].

The results for the estimation of model using human resource disclosures score (HRDS) as dependent variable are presented in Table 8. As expected, NEP, FOREIGN and TYPE are positively related to HRDS. The results for model show that 100 units increase in number of employees creates $7.2 \%$ increase in human resource disclosure scores. Moreover, type of insurance companies results in increase in human resource disclosure.

Table 8. Results of Pooled OLS regression analysis.

\begin{tabular}{|c|c|c|}
\hline Variables & Predicted Sign & Pooled OLS \\
\hline ROA & Positive & $\begin{array}{c}0.04203 \\
(0.509)\end{array}$ \\
\hline ROE & Positive & $\begin{array}{c}0.00051 \\
(0.001)\end{array}$ \\
\hline LEV & Positive & $\begin{array}{c}-0.12396 \\
(0.169)\end{array}$ \\
\hline SIZE & Positive & $\begin{array}{c}0.09224 \\
(0.064)\end{array}$ \\
\hline NEP & Positive & $\begin{array}{c}0.00072^{* *} \\
(0.000)\end{array}$ \\
\hline AGE & Positive & $\begin{array}{c}0.00080 \\
(0.003)\end{array}$ \\
\hline BIST & Positive & $\begin{array}{l}0.5005 \\
(0.331) \\
\end{array}$ \\
\hline FOREIGN & Positive & $\begin{array}{c}0.43875 \\
(0.162)^{* * *}\end{array}$ \\
\hline TYPE & Positive & $\begin{array}{c}0.33805 \\
(0.164)^{* *}\end{array}$ \\
\hline Constant & \multicolumn{2}{|c|}{$\begin{array}{l}-0.464 \\
(1.156)\end{array}$} \\
\hline YEAR DUMMY & \multicolumn{2}{|c|}{ Included } \\
\hline R-squared & \multicolumn{2}{|c|}{0.306} \\
\hline F-statistic & \multicolumn{2}{|c|}{10.84} \\
\hline Clusters & \multicolumn{2}{|c|}{54} \\
\hline Ramsey's Reset test & \multicolumn{2}{|c|}{0.0576} \\
\hline
\end{tabular}

Notes: ${ }^{*}{ }^{* *}, * * *=$ statistically significant at less than $0.10,0.05$ and 0.01 level. Dependent variable: human resources disclosure. This table presents estimates from pooled OLS regressions explaining HRDS (Human Resources Disclosures Score), which is measured by the natural logarithm of total sentence number link to the employee issues in the firm's corporate report between 2007-2017. We define TYPE (type of insurance company, 1 if the insurance company is life insurance, 0 otherwise). Standard errors are robust to heteroscedasticity and are clustered at the year. Year dummies and constant term in the regressions. The model specifications employ robust standard errors and robust $t$-statistics are reported in the parentheses below each coefficient. Abbreviations used: return on assets (ROA), return on equity (ROE), leverage (LEV), size (SIZE), number of employees (NEP), firm age (AGE), public listing status (BIST), foreign ownership (FOREGING) and type of firm (TYPE)

In addition, that if the firm has foreign shareholders in capital and the firm is a life insurance company, the HRDS increases, respectively, approximately $44 \%$ and $34 \%$. Other variables individually 
insignificant. The result of the Ramsey Reset test shows a $p$-value of 0.0566 , implying that the null hypothesis that model has no omitted variables may be accepted. The significant year dummy clearly implies that there is a significant time effect on the relationship among the variables.

The results show that F-statistic is 10.84 and Prob (F-statistic) $=0.0000$, it implies that the overall model is statistically significant. In addition, the adjusted R-squared of 0.3060 indicate explanatory power of the independent variables in the extent of human resources disclosure.

Table 9 presents the results of Pooled OLS regression analysis for all our hypotheses.

Table 9. Summary of test results.

\begin{tabular}{cc}
\hline Hypothesis & Result \\
\hline H1 & Rejected \\
H2 & Rejected \\
H3 & Rejected \\
H4 & Rejected \\
H5 & Supported \\
H6 & Rejected \\
H7 & Rejected \\
H8 & Supported \\
H9 & Supported \\
\hline
\end{tabular}

\section{Conclusions and Discussion}

Many determinants of human resource disclosure were empirically investigated in previous studies. In this study, to understand the relationship between potential company characteristics in insurance companies and the extent of human resource disclosures scores, we used return on assets (ROA), return on equity (ROE), leverage (LEV), size (SIZE), number of employees (NEP), firm age (AGE), public listing status (BIST), foreign ownership (FOREGING) and type of firm (TYPE) as determinants in research model by collecting data from company's annual reports between 2007-2017 years.

In distribution of human resources disclosures items, most disclosed human resource information belongs to employee training. This finding is also supported in Vuontisjarvi's [29] study. He stated that the most reported theme was training and staff development in annual reports. In Turkey, professional training and development is among the first most important attributes for company attractiveness according to Universum's 2019 The Most Attractive Employers in Turkey Report [92]. In addition, corporate reports are information channels to gain support of current and potential employees as stakeholders to inform training and development policies. On the other hand, information about disabled employees is the least disclosure item in corporate reports. Turkey has efforts to increase employment of disabled employees in labor market [93]. As a part of diversity programs, business make disabled-friendly policies in workplaces and disclose this information in their reports, but disclosures are not enough for insurance sector companies as appeared in our study.

The findings indicate that the extent of human resources disclosure depends on some company characteristics. It is appeared that number of employees, foreign ownership and type of firm explained significantly to the human resource disclosures. These results were also supported by several empirical studies in the recent literature $[28,39,80,81]$. These implies that companies with higher number of employees and with foreign ownership are more likely to disclose human related information. In addition, these findings are in line with other financial institutions, namely bank disclosure [94] and recent research on the agency issues [95,96] and insurance sector [74]. Ullah et al. [74] and Orazalin [94] indicated that ownership is correlated to the extent of corporate social responsibility disclosures in insurance companies. The companies are service companies and human resources in the companies have direct contact to customers and important role in value creation. When the number of employees increased, companies will be particularly motivated and responsible to disclose human resource information [97]. In addition, foreign ownership can be shaped by foreign countries' practices and regulations. In addition, regarding the type of insurance company, being life and non-life insurance 
company may effect companies' human resource disclosures as stated in Das [38] and Ullah et al.'s [74] studies. On the other hand, ROA, ROE, leverage, size, firm age and public listing status were found insignificant. ROE, leverage, size, firm age and public listing status are correlated to human resource disclosures. But there is no link can be found between ROE and human resource disclosures.

\section{Limitations and Future Research Direction}

One of the main limitations of this study is that the findings are limited to sampled companies in insurance sector which may not be generalized to other sector companies. This study used annual reports to analyze human resource disclosures. Other studies can be taken in the other sectors that voluntarily report human resource disclosures and other communication channels such as sustainability reports, corporate web page, social media. More empirical research should be conducted both in developed and developing countries to show importance of human resources in business life.

Author Contributions: E.E. wrote the introduction part and theoretical framework. A.Ö.Ç. designed the research methodology, F.B.S. collected and analyzed the data. A.Ö.Ç. reported the analysis and wrote the methodology section. A.Ö.Ç and E.E. read and edited the last version of manuscript. All authors have read and agreed to the published version of the manuscript.

Funding: This research received no external funding.

Conflicts of Interest: The authors declare no conflict of interest.

\section{References}

1. Brown, A.M.; Tower, G.; Taplin, R. Human resources disclosures in the annual reports of Pacific Island countries' entities. Asia Pac. J. Hum. Resour. 2005, 43, 252-272. [CrossRef]

2. Dominguez, A.A. The impact of human resource disclosure on corporate image. J. Hum. Resour. Costing Account. 2011, 8, 4-20.

3. Petera, P.; Wagner, J. Human resources disclosure among companies in Czechia. Soc. Responsib. J. 2017, 13, 743-761. [CrossRef]

4. Samudhram, A.; Sivalingam, G.; Shanmugam, B. Non-disclosure of human capital-based information: Theoretical perspectives. J. Hum. Resour. Costing Account. 2010, 14, 106-128. [CrossRef]

5. Abeysekera, I.; Guthrie, J. Human capital reporting in a developing nation. Br. Account. Rev. 2004, 36, 251-268. [CrossRef]

6. Guthrie, J.; Petty, R. Intellectual capital: Australian annual reporting practices. J. Intellect. Cap. 2000, 1, 241-251. [CrossRef]

7. Olsson, B. Annual reporting practices: Information about human resources in corporate annual reports in major Swedish companies. J. Hum. Resour. Costing Account. 2001, 6, 39-52. [CrossRef]

8. Brennan, N. Reporting intellectual capital in annual reports: Evidences form Ireland. Account. Audit. Account. J. 2001, 14, 423-436. [CrossRef]

9. Bozzolan, S.; Favotto, F.; Ricceri, F. Italian annual intellectual capital disclosure: An empirical analysis. J. Intellect. Cap. 2003, 4, 543-558. [CrossRef]

10. Ali, W.; Frynas, J.G.; Mahmood, Z. Determinants of corporate social responsibility (CSR) disclosure in developed and developing countries: A literature review. Corp. Soc. Responsib. Environ. Manag. 2017, 24, 273-294. [CrossRef]

11. Vadlamannati, K.C. Do insurance sector growth and reforms affect economic development? Empirical evidence from India. Margin J. Appl. Econ. Res. 2008, 2, 43-86. [CrossRef]

12. Insurance and Financial Stability. Available online: https://www.bankofengland.co.uk/ -/media/boe/files/quarterly-bulletin/2015/insurance-and-financial-stability.pdf?la=en\&hash= 9C63E3137BF1F88EF2502F6E0F44A3A7DC54B278 (accessed on 7 January 2020).

13. Rashidi, K.; Stadelmann, M.; Patt, A. Creditworthiness and climate: Identifying a hidden financial co-benefit of municipal climate adaptation and mitigation policies. Energy Res. Soc. Sci. 2019, 48, 131-138. [CrossRef] 
14. Hazine ve Maliye Bakanlığı (HMB). 2017 Yılı Türkiye'de Sigortacılık ve Bireysel Emeklilik Faaliyetleri Hakkında Rapor. Available online: https://www.hmb.gov.tr/sigortacilik-ve-ozel-emeklilik-raporlari\# (accessed on 7 January 2020).

15. Abhayawansa, S.; Abeysekera, I. An explanation of human capital disclosure from the resource-based perspective. J. Hum. Resour. Costing Account. 2008, 12, 51-64. [CrossRef]

16. Rimmel, G. Human Resources Disclosures A Comparative Study of Annual Report Practice About Information, Providers and Users in Two Corporations; Intellecta DocuSys: Göteborg, Sweden, 2003; pp. 1-206.

17. Pisano, S.; Lepore, L.; Lamboglia, R. Corporate disclosure of human capital via LinkedIn and ownership structure. J. Intellect. Cap. 2017, 18, 102-127. [CrossRef]

18. Bozzolan, S.; O’Regan, P.; Ricceri, F. Intellectual capital disclosure (ICD). J. Hum. Resour. Costing Account. 2006, 10, 92-113. [CrossRef]

19. Dhaliwal, D.S.; Li, O.Z.; Tsang, A.; Yang, Y.G. Voluntary nonfinancial disclosure and the cost of equity capital: The initiation of corporate social responsibility reporting. Account. Rev. 2011, 86, 59-100. [CrossRef]

20. Chan, M.C.; Watson, J.; Woodliff, D. Corporate governance quality and CSR disclosures. J. Bus. Ethics 2014, 125, 59-73. [CrossRef]

21. Hossain, M.; Hammami, H. Voluntary disclosures in the annual reports of an emerging country: The case of Qatar. Adv. Account. 2009, 25, 255-265. [CrossRef]

22. Chung, H.; Judge, W.Q.; Li, Y.-H. Voluntary disclosure, excess executive compensation, and firm value. J. Corp. Financ. 2015, 32, 64-90. [CrossRef]

23. Subbarao, A.V.; Zéghal, D. Human resources information disclosure in annual reports: An international comparison. J. Hum. Resour. Costing Account. 1997, 2, 53-73. [CrossRef]

24. Arvidsson, S. Disclosure of non-financial information in the annual report. J. Intellect. Cap. 2011, 12, $277-300$. [CrossRef]

25. Stone, R.J. Human Resource Management; John Wiley and Sons: Brisbane, Australia, 1998.

26. Greenwood, M.R. Ethics and HRM: A review and conceptual analysis. J. Bus. Ethics 2002, 36, 261-278. [CrossRef]

27. Bukh, P.N. The relevance of intellectual capital disclosure: A paradox? Account. Audit. Account. J. 2003, 16, 49-56. [CrossRef]

28. Kaur, S.; Raman, V.A.; Singhania, M. Impact of corporate characteristics on human resource disclosures. Asian Rev. Account. 2016, 24, 390-425. [CrossRef]

29. Vuontisjärvi, T. Corporate social reporting in the European context and human resource disclosures: An analysis of Finnish companies. J. Bus. Ethics 2006, 69, 331-354. [CrossRef]

30. Domínguez, M.A.Á. Company characteristics and human resource disclosure in Spain. Soc. Responsib. J. 2012, 8, 4-20. [CrossRef]

31. Türkiye Sigorta Birliği (TSB). Available online: https://www.tsb.org.tr/default.aspx?pageID=654\&yid=59 (accessed on 3 April 2020).

32. International Financial Reporting Standards Foundation (IFRS). Available online: https://www.ifrs.org/usearound-the-world/use-of-ifrs-standards-by-jurisdiction/turkey/ (accessed on 3 April 2020).

33. Kansal, M.; Joshi, M. Reporting human resources in annual reports: An empirical evidence from top Indian companies. Asian Rev. Account. 2015, 23, 256-274. [CrossRef]

34. Branco, M.C.; Rodrigues, L.L. Social responsibility disclosure: A study of proxies for the public visibility of Portuguese banks. Sci. Direct 2008, 40,161-181. [CrossRef]

35. Murthy, V.; Abeysekera, I. Human capital value creation practices of software and service exporter firms in India. J. Hum. Resour. Costing Account. 2007, 11, 84-103. [CrossRef]

36. Elo, S.; Kyngäs, H. The qualitative content analysis process. J. Adv. Nurs. 2008, 62, 107-115. [CrossRef] [PubMed]

37. Bayoud, N.S.; Kavanagh, M.; Slaughter, G. Factors influencing levels of corporate social responsibility disclousure by libyan firms: A mixed study. Int. J. Econ. Financ. 2012, 4, 13-29. [CrossRef]

38. Das, S.C. Corporate social reporting and human resource disclosures: Experiences from insurance companies in India. Soc. Responsib. J. 2013, 9, 1-16. [CrossRef]

39. Gamerschlag, R.; Möller, K.; Verbeeten, F. Determinants of voluntary CSR disclosure: Empirical evidence from Germany. Rev. Manag. Sci. 2011, 5, 233-262. [CrossRef] 
40. Ismail, K.N.I.; İbrahim, A.H. Social and environmental disclosure in the annual reports of jordanian companies. Issues Soc. Environ. Account. 2009, 2, 198-210. [CrossRef]

41. Menassa, E. Corporate social responsibility an exploratory study of the quality and extent of social disclosures by Lebanese commercial banks. J. Appl. Account. Res. 2010, 11, 4-23. [CrossRef]

42. Suher, İ. Zirvedeki Türk işletmelerinin kurumsal sosyal sorumluluk iletişimi: Web sitelerine yönelik bir inceleme. Selçuk Üniversitesi İletişim Fakültesi Akademik Dergisi 2010, 6, 33-48.

43. Tagesson, T.; Blank, V.; Broberg, P.; Collin, S. What Explains the extent and content of social and environmental disclosures on corporate websites: A study of social and environmental reporting in swedish listed corporations. Corp. Soc. Responsib. Environ. Manag. 2009, 16, 352-364. [CrossRef]

44. Milne, M.J.; Adler, R.W. Exploring the reliability of social and environmental disclosures content analysis. Account. Audit. Account. J. 1999, 12, 237-256. [CrossRef]

45. Hackston, D.; Milne, M.J. New some determinants of social and environmental disclosures in New Zealand companies accounting. Audit. Account. J. 1996, 9, 77-108. [CrossRef]

46. Zaini, S.M.; Sharma, U.; Samkin, G.; Davey, H. Impact of ownership structure on the level of voluntary disclosure: A study of listed family-controlled companies in Malaysia. Account. Forum 2020, 44, 1-34. [CrossRef]

47. Guthrie, J.; Abeysekera, I. Content analysis of social, environmental reporting: What is new? J. Hum. Resour. Costing Account. 2006, 10, 114-126. [CrossRef]

48. Kent, P.; Zunker, T. A stakeholder analysis of employee disclosures in annual reports. Account. Financ. 2017, 57, 533-563. [CrossRef]

49. Belkaoui, A.; Karpik, P.G. Determinants of the corporate decision to disclose social information. Account. Audit. Account. J. 1989, 2, 36-51. [CrossRef]

50. Skouloudis, A.; Jones, N.; Malesios, C.; Evangelinos, K. Trends and determinants of corporate non-financial disclosure in Greece. J. Clean. Prod. 2014, 68, 174-188. [CrossRef]

51. Ahmed, K.; Courtis, J.K. Associations between corporate characteristics and disclosure levels in annual reports: A meta-analysis. Br. Account. Rev. 1999, 31, 35-61. [CrossRef]

52. Xiao, J.Z.; Yang, H.; Chow, C.W. The determinants and characteristics of voluntary Internet-based disclosures by listed Chinese companies. J. Account. Public Policy 2004, 23, 191-225. [CrossRef]

53. Barakat, F.S.; Pérez, M.V.L.; Ariza, L.R. Corporate social responsibility disclosure (CSRD) determinants of listed companies in Palestine (PXE) and Jordan (ASE). Rev. Manag. Sci. 2015, 9, 681-702. [CrossRef]

54. Haniffa, R.M.; Cooke, T.E. The impact of culture and governance on corporate social reporting. J. Account. Public Policy 2005, 24, 391-430. [CrossRef]

55. Khemir, S.; Baccouche, C. Analysis of the determinants of corporate social responsibility disclosure in the annual reports of Tunisian listed firms. Res. Account. Emerg. Econ. 2010, 10, 119-144.

56. Cowen, S.S.; Ferreri, L.B.; Parker, L.D. The impact of corporate characteristics on social responsibility disclosure: A typology and frequency-based analysis. Account. Organ. Soc. 1987, 12, 111-122. [CrossRef]

57. Vazakidis, A.; Stavropoulos, A.; Galani, D. Company characteristics and human resource disclosure in greece, procedia technology. In Proceedings of the 6th International Conference on Information and Communication Technologies in Agriculture, Food and Environment (HAICTA 2013), Corfu Island, Greece, 19-22 September 2013; Volume 8, pp. 112-121. Available online: https://www.sciencedirect.com/science/ article/pii/S2212017313000789 (accessed on 12 February 2020).

58. Ng, E.J.; Koh, C.H. An agency theory and probit analytic approach to corporate non-mandatory disclosure compliance. Asia-Pac. J. Account. 1994, 1, 29-44. [CrossRef]

59. Kılıç, M.; Kuzey, C. The effect of corporate governance on carbon emission disclosures. Int. J. Clim. Chang. Strateg. Manag. 2019, 11, 35-53. [CrossRef]

60. Branco, M.C.; Rodrigues, L.L. Exploring the importance of social responsibility disclosure for human resources. J. Hum. Resour. Costing Account. 2009, 13, 186-205. [CrossRef]

61. Jensen, M.; Meckling, W.H. The theory of firm: Managerial behavior, agency costs and ownership structure. J. Financ. Econ. 1976, 3, 305-360. [CrossRef]

62. Cui, J.; Jo, H.; Na, H. Does corporate social responsibility affect information asymmetry? J. Bus. Eth. 2018, 148, 549-572. [CrossRef]

63. Naser, K.; Al-Hussaini, A.; Al-Kwari, D.; Nuseibeh, R. Determinants of corporate social disclosure in developing countries: The case of Qatar. Adv. Int. Account. 2006, 19, 1-23. [CrossRef] 
64. Hossain, M.; Perera, M.H.B.; Rahman, A.R. Voluntary disclosure in the annual reports of New Zealand companies. J. Int. Financ. Manag. Account. 1995, 6, 69-87. [CrossRef]

65. Garg, M.C.; Kumar, S. The relationship between human resource disclosure and company characteristics: A study on Indian companies. IUP J. Appl. Financ. 2019, 25, 28-47.

66. Oliveira, L.; Rodrigues, L.L.; Craig, R. Firm-specific determinants of intangible reporting: Evidence from the Portuguese stock market. J. Hum. Resour. Costing Account. 2006, 10, 11-33. [CrossRef]

67. Uyar, A.; Kilic, M. The influence of firm characteristics on disclosure of financial ratios in annual reports of Turkish firms listed in the Istanbul Stock Exchange. Int. J. Account. Audit. Perform. Eval. 2012, 8, 137-156. [CrossRef]

68. Aggarwal, K.; Verma, A. Effect of company characteristics on human resource disclosure index: Empirical evidences from Indian corporates. Manag. Labour Stud. 2020, 45, 85-117. [CrossRef]

69. Cormier, D.; Magnan, M. Corporate environmental disclosure strategies: Determinants, costs and benefits. J. Account. Audit. Financ. 1999, 14, 429-451. [CrossRef]

70. Frost, G.R.; Seamer, M. Adoption of environmental reporting and management practices: An analysis of New South Wales public sector entities. Financ. Account. Manag. 2002, 18, 103-127. [CrossRef]

71. Owusu-Ansah, S. The impact of corporate attributes on the extent of mandatory disclosure and reporting by listed companies in Zimbabwe. Int. J. Account. 1998, 33, 605-631. [CrossRef]

72. Zaid, M.; Wang, M.; Abuhijleh, S. The effect of corporate governance practices on corporate social responsibility disclosure: Evidence from Palestine. J. Glob. Responsib. 2019, 10, 134-160. [CrossRef]

73. Hamid, F.Z.A. Corporate social disclosure by banks and finance companies: Malaysian evidence. Corp. Ownersh. Control 2004, 1, 118-130. [CrossRef]

74. Ullah, M.; Muttakin, M.; Khan, A. Corporate governance and corporate social responsibility disclosures in insurance companies. Int. J. Account. Inf. Manag. 2019, 27, 284-300. [CrossRef]

75. Jindal, S.; Kumar, M. The determinants of HC disclosures of Indian firms. J. Intell. Cap. 2012, 13, $221-247$. [CrossRef]

76. Alam, I.; Deb, S.K. Human resource accounting disclosure (HRAD) in Bangladesh: Multifactor regression analysis-A decisive tool of quality assessment. Cost Manag. 2010, 38, 9-13.

77. Kiliç, M.; Kuzey, C.; Uyar, A. The impact of ownership and board structure on Corporate Social Responsibility (CSR) reporting in the Turkish banking industry. Corp. Gov. Int. J. Bus. Soc. 2015, 15, 357-374. [CrossRef]

78. Teoh, H.; Thong, G. Another look at corporate social responsibility reporting: An empirical investigation in developing country. Account. Organ. Soc. 1984, 9, 186-206. [CrossRef]

79. El-Bannany, M. A study of determinants of social disclosure level in UK banks. Corp. Ownersh. Control 2007, 5, 120-130. [CrossRef]

80. Bowrin, A.R. Human resources disclosures by African and Caribbean companies. J. Account. Emerg. Econ. 2018, 8, 244-278. [CrossRef]

81. Douglas, A.; Doris, J.; Johnson, B. Corporate social reporting in Irish financial institutions. TQM Mag. 2004, 16, 387-395. [CrossRef]

82. Cai, J.; Zhang, Z. Capital Structure Dynamics and Stock Returns. Available online: https://papers.ssrn.com/ sol3/papers.cfm?abstract_id=685462 (accessed on 3 April 2020).

83. KPMG. Sigortacılık: Sektörel Bakış 2019. Available online: https://assets.kpmg/content/dam/kpmg/tr/pdf/ 2019/05/sektorel-bakis-2019-sigortacilik.pdf (accessed on 3 April 2020).

84. Thelwall, M.; Wilson, P. Regression for citation data: An evaluation of different methods. J. Informetr. 2014, 8, 963-971. [CrossRef]

85. Cimenler, O.; Kingsley, A.R.; Skvoretz, J. A regression analysis of researchers' social network metrics on their citation performance in a college of engineering. J. Informetr. 2014, 8, 667-682. [CrossRef]

86. Jannot, A.-S.; Agoritsas, T.; Gayet-Ageron, A.; Perneger, T.V. Citation bias favoring statistically significant studies was present in medical research. J. Clin. Epidemiol. 2013, 66, 296-301. [CrossRef]

87. Tomczak, S.K.; Staszkiewicz, P. Cross-country application of manufacturing failure models. J. Risk Financ. Manag. 2020, 13, 34. [CrossRef]

88. Cook, R.D.; Weisberg, S. Diagnostic for heteroskedasticity in regression. Biometrika 1983, 70, 1-10. [CrossRef]

89. White, H. A heteroskedasticity-consistent covariance matrix estimator and a direct test for heteroskedasticity. Econometrica 1980, 48, 817-838. [CrossRef] 
90. Vurro, C.; Perrini, F. Making the most of corporate social responsibility reporting: Disclosure structure and its impact on performance. Corp. Gov. Int. J. Bus. Soc. 2011, 11, 459-474. [CrossRef]

91. STATA. Stata User's Guide (STATA Release 14); Stata Press: College Station, TX, USA, 2017.

92. Universum 2019. The Most Attractive Employers in Turkey. Available online: https://universumglobal.com/ rankings/turkey/ (accessed on 12 March 2020).

93. Yilmaz, V. An examination of disability and employment policy in Turkey through the perspectives of disability non-governmental organizations and policy-makers. Disabil. Soc. 2019, 1-23. [CrossRef]

94. Orazalin, N. Corporate governance and Corporate Social Responsibility (CSR) disclosure in an emerging economy: Evidence from commercial banks of Kazakhstan. Corp. Gov. Int. J. Bus. Soc. 2019, 19, 490-507. [CrossRef]

95. Staszkiewicz, P.; Szelagowska, A. Ultimate owner and risk of company performance. Econ. Res.-Ekon. Istraživanja 2019, 32, 3795-3812. [CrossRef]

96. Alshbili, I.; Elamer, A.; Beddewela, E. Ownership types, corporate governance and corporate social responsibility disclosures: Empirical evidence from a developing country. Account. Res. J. 2019, 33, 148-166. [CrossRef]

97. Jizi, M.I.; Salama, A.; Dixon, R.; Stratling, R. Corporate governance and corporate social responsibility disclosure: Evidence from The US banking sector. J. Bus. Ethics 2014, 125, 601-615. [CrossRef]

(C) 2020 by the authors. Licensee MDPI, Basel, Switzerland. This article is an open access article distributed under the terms and conditions of the Creative Commons Attribution (CC BY) license (http://creativecommons.org/licenses/by/4.0/). 